\title{
Service Barometers
}

\author{
Using Lending Kiosks to Locate Patrons \\ William Yarbrough
}

Public libraries have been using lending kiosks for close to ten years now. Typically, kiosks are used as a sort of satellite collection, delivering library services directly to the community. Often, they target people with limited mobility or who lack reliable transportation. Reaching these underserved populations helps expand a library's service area and users, which can factor in to state aid.

But when Amanda Jackson first took over as Director for the Chesapeake Public Library, back in 2018, one of her first ideas involved using lending kiosks in a way that's slightly unconventional.

Chesapeake is the second largest city in the Commonwealth of Virginia, measuring at 350 square miles. While considered suburban, the city is also plenty rural, with large areas of farmland, forest, swamps, and river.

One of those areas is Southern Chesapeake. Spanning roughly 130 square miles, Southern Chesapeake stretches all the way down to the border with North Carolina. The closest library, however, is located on the northern end of the city, all the way up in Great Bridge. This library, which houses over 289,000 items (not to mention a Law Library and History Room), is the largest in the city. More than 500,000 people visit it annually. Still, for many of the 19,586 residents in Southern Chesapeake, it's a bit of a hike.

For this size population, breaking ground on a new library branch would be warranted. Especially since that population is growing. From 2018 to 2019, Southern Chesapeake saw its population increase by $1.62 \%$, good for second highest among the city's nine boroughs. But even a small library, of, say, 12,000 square feet, would cost \$3 million-and that's being conservative. Justifying that big of an expense, both to the city council and local taxpayers, requires proving a return on investment.

"Building a new library brings a lot of excitement and energy into the community," Jackson says. "But first, to support that decision, we need to better understand what South Chesapeake needs from the library."

The first person Jackson turned to was Maiko Medina, who heads up CPL's IT Division. Like Jackson, Medina has worked in libraries for close to 20 years, first as frontline staff before transitioning to IT. While with the neighboring Virginia Beach Public Library System, he helped install a variety of new systems, including self-checkout kiosks.

Together, Medina and Jackson came up with a plan, that uses lending kiosks as a type of service barometer. CPL would install kiosks all around South Chesapeake, at city parks, community

William Yarbrough (wyarbrou@infopeake.org) is Administrative Assistant, Chesapeake Public Library. (C) 2021. 
centers, police and fire stations, and local businesses. Each kiosk would provide a selection of new and popular items from the library's catalogue, from which patrons could check out on the spot.

"By studying how the kiosks are used, we'll get a better idea for where our patrons are," Medina says. "It'll also tell us what they're interested in."

This plan was submitted as a capital project. At a proposed $\$ 113,000$, the project would fund one initial lending kiosk, along with an accompanying holds locker. Chesapeake City Council approved this project for fiscal year 2020. Installation of the first kiosk in Southern Chesapeake was then scheduled for 2021. However, when the COVID-19 pandemic hit, Jackson, Medina and the rest of the team at CPL recognized the need to speed the plan into action.

"We kept hearing about how kids were struggling with virtual learning," Jackson says, "especially those in our underserved communities."

One of those communities is South Norfolk. Among the neighborhood's 22,851 residents, 59.2\% identify as Black. $31 \%$ are 19 or younger. Of those children, $39 \%$ are enrolled at a Title I School. As schools were forced to move learning online, many of these students fell behind, whether because they lacked reliable Internet, access to a home computer, or both.

To meet this need, the neighboring Dr. Clarence V. Cuffee Library was transformed into an Outreach and Innovation Center. Along with a business center, maker spaces, STEM walls, and a rotating art gallery, the new-and-improved Cuffee Library came with a student learning center. Through this service, students can schedule one-on-one tutoring appointments with library staff and local college students, either virtual or in-person.

Of course, adding these new services required moving other things around. Books, DVDs, and other materials were redistributed to other libraries across the system. This may seem like an odd decision (after all, what's a library without books?). But patrons weren't using this library for materials; in fact, the number of items checked out from the collection $(17,922)$ was significantly lower than any of the other six branches.

Still, the Library didn't want to abandon those patrons who rely on Cuffee for more traditional services. Especially since many were likely stuck at home during the pandemic.

To meet this need, last October, shortly after the newly renovated Dr. Clarence V. Cuffee Outreach and Innovation Center opened, rather than wait until 2021, the library secured additional funding, through the CARES Act, to install a lending kiosk right outside the center's main entrance. With this kiosk-a LendIT 200 (courtesy of D-Tech International) - patrons can check out from a rotating list of 200 items. They can also get any other item in the library' collection by using the HoldIT locker (also from D-Tech). Both services are free and are available 24 hours a day, 7 days a week.

So far, since last December, 136 items have been checked out through the Cuffee LendIT kiosk. Another 304 have been checked out via the holds locker. Among those check-outs, most popular are Adult Nonfiction DVDs (33\%) and Adult Fiction books (20\%). As a result, more of these items will be rotated into the kiosk's collection. Not only that, but next month, the library will break 
ground on another, bigger lending kiosk. Located at Fire Station 7, this kiosk will be the first LendIT 500 installed in South Chesapeake.

"The lending kiosk has really helped us continue to serve our patrons during all the changes brought on over the past 18 months," say both Jackson and Medina. "Now that things are starting to move ahead a little, we're excited for how this technology will help us reach more of Chesapeake."

Over the next couple of years, Chesapeake Public Library will use these lending kiosks to learn more about what the growing number of people in South Chesapeake need from the library. Maybe that's more kiosks, a small storefront or even a full-sized, brick-and-mortar building. Either way, new and innovative technologies like the lending kiosks will lead the way, helping CPL deliver services further into the community. 